\title{
Asymmetric crying facies - its meaning in the differential diagnosis of congenital developmental abnormalities
}

\section{Asymmetric crying facies - znaczenie w diagnostyce różnicowej wrodzonych wad rozwojowych}

\author{
Agata Michalska¹, Katarzyna Połatyńska², Łukasz Kępczyński³, Maciej Szczukocki \\ 'Departament of Physiotherapy, Collegium Medicum, Jan Kochanowski University, Kielce, Poland \\ Head of the Department: Prof. Zbigniew Śliwiński \\ ${ }^{2}$ Departament of Neurology, Polish Mother's Memorial Hospital Research, Lodz, Poland \\ Head of the Department: Łukasz Przysło PhD \\ ${ }^{3}$ Department of Genetics, Polish Mother's Memorial Hospital Research, Lodz, Poland \\ Head of the Department: Agnieszka Gach PhD \\ ${ }^{4}$ Departament of Pediatric and Pediatric Surgery, Collegium Medicum, Jan Kochanowski University, Kielce, Poland \\ Head of the Department: Prof. Mieczyslaw Szalecki
}

Key words: differential diagnosis, face asymmetry, asymmetric crying facies (ACF).

Słowa kluczowe: diagnostyka różnicowa, asymetria twarzy, asymmetric crying facies (ACF).

\begin{abstract}
The symmetry of a newborn baby's head and face, including the symmetry of a palpebral fissure, auricles, nose, and the movement of eyelids and mouth, is evaluated during a newborn baby's overall examination. Asymmetric crying facies (ACF) is a congenital disorder resulting from unilateral hypoplasia, or from agenesis of the depressor anguli oris muscle or rarely of the depressor of the edge of the mouth and depressor of labii inferioris. The ACF incidence rate oscillates at about $0.3 \%$, with the dominance of a left-handed disorder. Isolated ACF is treated as a cosmetic defect, although it can accompany a wide range of developmental disorders, the most common of which is congenital facial nerve palsy. In every case, a profound morphological and anatomical evaluation should be executed because, if necessary, the molecular analysis should be widened.
\end{abstract}

\section{Streszczenie}

Symetria głowy i twarzy noworodka, w tym symetria szpar powiekowych, małżowin usznych, nosa, a także ruchów powiek i ust, jest oceniana w ramach badania ogólnego noworodka. Asymmetric crying facies (ACF) jest wrodzonym zaburzeniem wynikającym z jednostronnej hipoplazji bądź agenezji mięśnia obniżacza ką̧a ust lub rzadziej mięśni obniżacza kąta ust i obniżacza wargi dolnej. Częstość występowania ACF wynosi około 0,3\%, z przewagą po stronie lewej. Izolowana ACF uznawana jest za defekt kosmetyczny, chociaż może towarzyszyć różnorodnym zaburzeniom rozwojowym. Wśród nich na pierwszym miejscu wymienia się wrodzone porażenie nerwu twarzowego. W każdym przypadku należy przeprowadzić szczegółową ocenę morfologiczną i anatomiczną, w razie potrzeby poszerzoną o analizę molekularną.

\section{Introduction}

The symmetry of a newborn baby's head and face, including the symmetry of the palpebral fissure, auricles, nose, and the movement of eyelids and mouth, are evaluated during a newborn baby's overall examination. The determination of the presence of a pathological facial asymmetry requires a detailed analysis of its potential causes. Amongst them, facial nerve palsy is quoted as the major one, existing as an isolated disorder or intercurrent with other symptoms in the course of, amongst others, a cardiofacial syndrome, Möbius syndrome, Poland syndrome, CHARGE, or Goldenhar syndrome [1]. Despite them, in the differential diagnosis of newborn babies, what should be considered are congenital unilateral labii inferioris paralysis and minor inborn or psychogenic motivated asymmetries, resulting from individual expression patterns.

A congenital facial nerve palsy means the symptoms of a nerve palsy were already present when a baby was born. A congenital facial nerve paresis can be broken into types, according to aetiology (developmental or traumatic), localisation (unilateral or bilateral), and 
severity (total or partial). A total facial nerve paresis has an influence on a child's development, disrupting suction and, at a later age, the functions of chewing and speech. Moreover, as a result of the inadequacy of eyelid closure it leads to polluting a conjunctiva and chronic inflammations of saccus conjunctivae.

Congenital facial nerve palsy is relatively rare. Approximately, it occurs in $8-14 \%$ of all cases of a facial nerve paresis among children [2]. The incidence rate among live infants is at $0.8-2.1$ per 1000 births. It is therefore considered that the reason for its occurrence is a perinatal injury (88\%), mainly due to forceps being used [3]. However, there are reported cases of a paresis occurring among infants born prematurely assisted by artificial respiration, as a result of a long-lasting pressure of elements mounting a mask [4]. Other casual factors of facial asymmetry can be congenital disorders (cleft lip and palate, spina bifida, hemifacial microsomia, neurofibromatosis, torticollis, craniosynostoses, vascular diseases) [5].

Defects of the stem of a facial nerve among children manifest with facial asymmetry visible during facial expressions (forehead, nasolabial folds), inadequate palpebral fissure closure, and ipsilateral depression of the corner of the mouth in relation to the defect. On the grounds of the occurrence of the pathology outwith the central nervous system it would be called a peripheral facial nerve palsy. If the disease process affects a nerve core (emergent nucleus, motor nucleus in the pons), the asymmetry concerns the lower part of the face (depression of the corner of the mouth) and is referred to as a central defect.

In the case of an infant's facial asymmetry visible only during crying, manifesting itself with a unilateral depression of the corner of the mouth, we must predominantly exclude facial nerve palsy and its causes, and then consider the presence of a congenital unilateral lower lip palsy (CULLP).

\section{Asymmetric crying facies (ACF)}

CULLP is a disorder first mentioned in 1960 by Hoefnagel and Penry. In 1972 Pape and Pickering introduced a new term asymmetric crying facies (ACF). Presently the term neonatal asymmetric crying facies (NACF) is used as well, to emphasise its presence since birth [6]. Initially, ACF was wrongly perceived as partial facial paresis [7]. In fact, it is a congenital disorder resulting from unilateral hypoplasia, from agenesis of the depressor anguli oris muscle, or rarely of the depressor of the edge of the mouth and depressor of labii inferioris, muscles responsible for the movement of the mouth. The pathogenesis remains unknown. It is estimated that the reasons for hypoplasia are abnormalities associated with the development of the aforementioned muscles (primary or secondary, resulting from innervations) and prenatal or perinatal compression of a facial nerve (ramus marginalis mandibulae heading along a mandible edge to the lip muscles and the chin) or abnormalities of the development of a facial nerve. Potential aetiological factors are also infections of a TORCH group [6-8]. An intrauterine moulding and intrauterine infection at the time of forming neural connections seem to be the most likely causes of ACF [8]. On the grounds of neuromuscular conductivity research, we can conclude that in the majority of cases ACF is caused by neurodevelopmental abnormalities leading to muscular hypoplasia (80\%). The nerve compressions account for a much smaller percentage (20\%). It is favoured by the placement of ramus marginalis mandibulae of a facial nerve, just below the bottom edge a mandible (in adults located $2 \mathrm{~cm}$ lower). In the case of nerve compression, spontaneous disappearance of symptoms can occur, excluding subsequent consequences. ACF caused by abnormal development of a nerve results in settled neurological symptoms [7].

The ACF incidence rate oscillates at about $0.3 \%$. In the research of Lahat et al. [9] in a group of 5532 newborn babies the incidence rate was 3.1 per 1000 births, with dominance of left-side disorders. Similarly, in a cohort research of Dubnov-Raz et al. [10] it was 3.8 per 1000 births (258/67 289), also with a clear dominance of defects on the left side (77\%) and the prevalence of cases occurring with male newborns.

\section{Associated anomalies}

ACF can occur as an isolated disorder malformation, although commonly it is intercurrent with other malformations in syndromes of congenital anomalies. Ekici et al. [11] report the case of ACF coexisting with Marin-Amat syndrome, a rare facial synkinesis characterised by the closing of an eyelid upon full opening of the jaw. A described syndrome is the consequence of defects of nerve fibres in the place of emerging from the motor nucleus in the pons, similarly to MarcusGunn syndrome, which includes upper lid movement with jaw winking. A similar symptom to ACF is described with the eponym Nothnagel syndrome, and is connected with the damage of the neural connections between the thalamus and striatum. This symptom is characterised by the suspension of facial expressions triggered by emotions, maintaining the involuntary dyskinesia [12]. Initially, ACF was associated with congenital heart anomalies describing them as cardiofacial syndrome. In the research of Lin et al. [13] the coexistence of ACF together with other congenital diseases was reported in 70\% of cases. More interestingly, defects in the head and neck area were reported in $48 \%$ of subjects, whereas the congenital encephalos anomalies were only seen in $10 \%$ only. Anomalies of other systems have also been noted (cardiovascular $44 \%$, genitourinary $-24 \%$, skeletal structure $-22 \%$ ), with at least two being reported in almost half of the subjects. 
$\mathrm{ACF}$ as a dysmorphic symptom of genetically conditioned diseases and developmental abnormalities must be differentiated from related dysmorphic symptoms, namely facial asymmetry per se and a peculiar facial appearance while crying. Facial asymmetry per se has been widely commented on in the literature concerning dysmorphology and clinical genetics, and a differential diagnosis of this symptom exceeds this very elaboration. The picture of a peculiar facial appearance while crying without being accompanied by other dysfunctions of the face structure is a relatively infrequently observed dysmorphic symptom and in the literature is virtually associated only with a urofacial syndrome (UFS, Ochoa syndrome). UFS is a heterogenic nosologic unit including at least two types: UFS type 1 , caused by a homozygous mutation of an HPSE2 gene [14] and UFS type 2, caused by a homozygous mutation of an LRIG2 gene [15]. Dysmorphic anomalies of an inverted smile type are in either case accompanied by dysfunctions of the genitourinary tracts, leading to dysfunctions of bladder emptying and secondary complications in the form of vesicoureteral reflux, urinary tract infections, hydronephrosis, renal failure, and hypertension. Patients with UFS require, above all, urological and nephrological assistance. Dysmorphic changes represent in the majority of cases only a cosmetic defect, not requiring any correction.

Elaborating on a peculiar facial appearance while crying, it must be emphasised that the picture of several dysfunctions of the face structure, both asymmetrical and symmetrical, worsens when a child smiles, laughs, or cries, which must be considered when conducting a dysmorphological diagnosis.

ACF as a dimorphic symptom may: (1) be an isolated symptom; (2) be a part of nonrandomised multiple anomalies (MA) - clinical features not impairing the general condition of a patient, or being just a cosmetic defect; (3) be a part of a nonrandomised set of serious congenital diseases; or (4) be part of a set of congenital diseases accompanying mental disabilities (syndromic mental retardation, MA/MR, multiple anomalies/ mental retardation). There is, however, a lack of unambiguous data in the literature about inherited, isolated ACF. The cases of syndromic occurrence of ACF of a known genetic reasoning include Cayler cardiofacial syndrome (OMIM \#125520) and microduplications 7q11.23 (microduplications of a critical region of Williams-Beuren syndrome, OMIM \#609757). Moreover, we must emphasise the cases of ACF included in (and suspected of a genetic aetiology) Möbius syndrome (locus 13q12.2-q13) and the association VACTERL/VACTER. Assigning ACF to other monogenic or chromosome syndromes should be considered as an example of unclear differentiation between the facial asymmetry per se and ACF itself. Other than those mentioned, there are also described infrequent cases of associations (a nonrandomised set of congenital diseases without a single recognised causal agent) like the coexistence with Glanzmann's thrombasthenia [16], or a single central incisor, narrowing of an anterior nasal aperture, nonaxial foot underdevelopment [17], unilateral auricular malformation, patent foramen ovale, spinal malformations, and hemihyperplasia [18], situs inversus (a case ascribed to Cayler cardio-facial syndrome) [19], immunodeficiency and partial vitiligo (a case ascribed to Griscelli syndrome) [20], lamellar ichthyosis [21], agenesis of corpus callosum (two cases - one ascribed to neurofibromatosis type 1) [22] - those descriptions, however, predominantly have a casuistry value. Moreover, what has also been emphasised was an increased frequency of occurrences of congenital diseases of other organs and systems, inter alia central nervous system, heart, digestive system, skeletal, genitourinary tracts, and intellectual impairments $[13,23]$ without a formal introduction of the description of particular associations, which, due to the heterogenic picture, seems to be a proper attitude.

What loses a nomenclatural meaning is the term cardio-facial syndrome, described in 1969 [24] as intercurrent with congenital hypoplasia of the depressor anguli oris muscle and a congenital heart defect in the form of a cavity in the interventricular septum (supplemented with other heart defects by other authors at a later time). Currently, it is perceived as the form of the syndrome associated with microdeletion $22 q 11$ [25], which is confirmed by in a growing number of cases verified in a molecular manner [8, 26-28]. A team of Japanese researchers has described a case of a girl who was diagnosed with overlapping of the symptoms branchiootic syndrome (BOS) and a cardio-facial syndrome, inter alia ACF. A set of symptoms has been attributed to a mutation of the EYA1 gene, associated with BOS type 1 [29].

Microduplication syndrome 7q11.23 is a multisystem disorder of a changeable expression, including non-specific dysmorphic features, speech impediments, comprehensive developmental disabilities, and intellectual impairments of different degrees [30]. There has been described a single case of a boy who manifested ACF within a spectrum of symptoms of microduplication 7q11.23 [31].

Taking into consideration a spectrum of genetically verified reasons for the occurrence of $\mathrm{ACF}$, in children in whom MA or MA/MR features accompany this symptom, conducting a microdeletion test covering the chromosome regions $22 \mathrm{q} 11$ and $7 \mathrm{q} 11.23$ must be considered. However, it must be emphasised that as far as ACF can accompany a wide range of developmental disorders, in every case a profound morphological and anatomical evaluation should be executed because, if necessary, the molecular analysis should be widened. For the time being, the introduction of 
a molecular and cytogenetical analysis for patients with an isolated ACF seems to be unfounded.

\section{Symptoms and diagnosis}

Clinical symptoms of ACF are the result of the asymmetry in the structure and activity of the depressor anguli oris muscle, rarely of the depressor of the edge of the mouth and the depressor of labii inferioris, orbicularis oris muscles without coexisting defects of a facial nerve (nerve conductivity in a facial nerve does not show release) [32]. The depressor anguli oris muscle drags a corner of the mouth downwards and smoothens a nasolabial fold. This muscle shapes a lateral part of a bottom lip, and its contraction makes the shape of the mouth a convex arch upwards. The muscle is active during crying, and among older children also while expressing feelings of disgust, abomination, fury, despise, or fatigue. The depressor anguli oris muscle lowers and makes the bottom lip convex and is active while smiling [6]. Among newborns with ACF due to a functional asymmetry while crying or laughing, mouth fissure asymmetry is observed. Increased activity of the depressor anguli oris muscle on the unoccupied side causes dragging of the corner of the mouth towards a stronger muscle. The bottom lip on the side occupied with hypoplasia makes an impression of being thinner as a result of impairing its activity of making it convex (Figure 1). In the case of ACF, no symptoms characteristic for facial nerve palsy, like eyelid movement asymmetry, the depth of nasolabial folds, the impairment of suction or drooling, have been observed (Figure 2).

A facial asymmetry in a newborn is, on a regular basis, determined upon birth and requires an incisive physical examination. An ACF diagnosis is made on the basis of the clinical symptoms listed in Table 1 after having eliminated central facial nerve palsy. Neuroimaging is essential to this end. With newborns with an open fontanelle a quick and harmless examination is cranial ultrasound. By means of ultrasound, central nervous system haemorrhage, hydrocephalus, and some growth processes can be excluded. The application of this examination is, however, limited in case of the pathology in the rear base of the scull, namely cerebellum, pons and medulla oblongata. Hence, a patient showing the symptoms of central facial nerve palsy with lack of pathology with ultrasound should undergo computed tomography (CT) scan and magnetic resonance imaging (MRI). A valuable complement to neuroimaging is an electrophysiological test (a test for neuromuscular conductivity). It allows for differentiation of neurodevelopmental disorders in the nerves from their compression. The age of the patient is a limitation in this case. The examination may cause some discomfort, and lack of cooperation on behalf of a patient makes the interpretation confusing. A painless examination is muscle ultra- sound, which allows determination of the thickness of the muscle venter around the mouth fissure, which in turn allows for hypoplasia.

Serological examinations are mainly aimed at pathogens of the TORCH group. TORCH is an acronym of five infections covered in the screening (Toxoplasmia gondii, other diseases including HIV, HPV, B19, Rubella virus, Cytomegalovirus, Herpes virus). Fetopathy caused by pathogens of the TORCH group commonly resemble each other and are initially difficult to differentiate. Symptoms include: hepatosplenomegaly, non-physiological jaundice, intrauterine hypotrophy, premature birth, haematological

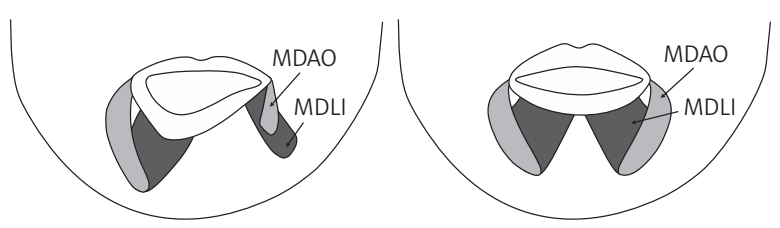

Figure 1 . The scheme shows the structure of the muscle around the mouth (on the left is hypoplasia of the depressor anguli oris muscle (MDAO) and the depressor labii inferioris muscle (MDLI) with a characteristic asymmetric mouth placement during activity; on the right a proper structure)
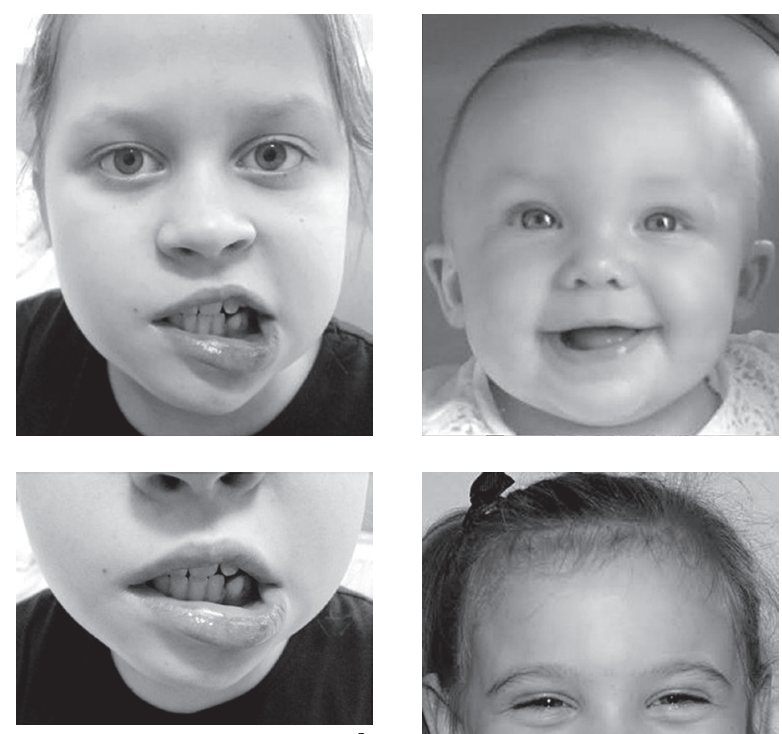

A

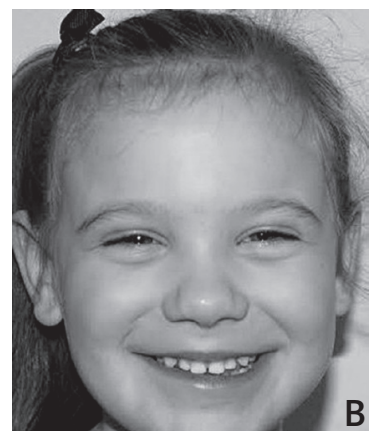

Figure 2. The comparison of a clinical picture of patients with a congenital central palsy of a facial nerve $(\mathbf{A})$ and ACF (B). In both cases, a mouth asymmetry is visible, while shallowing of the nasolabial furrow is the case only with a patient with a facial nerve palsy (own material, used with the parents' permission) 
Table 1. Symptom comparison of ACF and congenital facial nerve palsy

\begin{tabular}{|lcc|}
\hline Symptoms & $\begin{array}{c}\text { Asymmetric } \\
\text { crying facies }\end{array}$ & $\begin{array}{c}\text { A congenital facial } \\
\text { nerve palsy }\end{array}$ \\
$\begin{array}{l}\text { Unilateral depression of the corner of the } \\
\text { mouth while laughing or crying }\end{array}$ & Present & Present \\
$\begin{array}{l}\text { Decrease of the thickness of the bottom lip } \\
\text { on the affected side (visible while crying) } \\
\text { Resting symmetry of mouth fissure }\end{array}$ & Present & Present \\
Resting face symmetry & Yes & No \\
Symmetry of eyelid movement & Yes & No \\
& Yes & Depending of the place: \\
Suction & - the stem of the nerve - no, \\
Drooling & Intact & - core - yes \\
Depth of the nasolabial folds & Absent & Affected \\
Nostril movement while breathing & Symmetrical & Present \\
Autonomic symptoms & Symmetrical & Asymmetrical \\
Palate muscle movement & Absent & Present \\
& Intact & Depending of the place: \\
\hline
\end{tabular}

disorders, eye diseases (uveitis, inflammatory retinal diseases, cataract, glaucoma, keratitis, conjunctivitis, microphthalmia), and congenital encephalopathy (microcephaly, hydrocephalus, intracranial calcification syndrome), and among them facial nerve palsy. The suggested diagnostic proceedings in the case of determination of ACF are presented in Table 2.

\section{Management and prognosis}

Isolated ASF is treated as a cosmetic defect that does not significantly influence the orofacial area (labial and labiodental consonant articulation, food acquisition). With older children an asymmetry is visible only with particular activities (smiling, laughing, grimacing), and the degree of its intensity may decrease with age (Figure 3) [6, 8]. In the case of ACF resulting from the compression of a facial nerve, the symptoms may vanish by themselves in the first year of life [33].

The therapy of a facial asymmetry should be adjusted individually. In the case of ACF without any articulation disorders or issues with chewing, there is no need to introduce any conservative or invasive treatment. The most commonly taken measures are physiotherapeutic, aimed at restoring the functional facial symmetry, or speech therapy. Surgical treatment of a facial paresis remains questionable. Surgical techniques of facial asymmetry treatment rely on the reconstruction of the nerves and muscles by their transplantation and transposition [34]. Among surgeries quoted are the resection of the labii inferioris muscle, a selective resection of the ramus marginalis mandibulae, bidirectional fascia transplant, digastric

Table 2. Diagnostic proceedings

\begin{tabular}{|c|c|}
\hline Material and personal & Medical history and neurological examination \\
\hline Electrophysiological & Neuromuscular conductivity of a facial nerve \\
\hline Ultrasound scans & Muscles: depressor anguli oris depressor labii inferioris \\
\hline Serological & Antibodies to pathogens of a TORCH group \\
\hline Neuroimaging & Fontanel ultrasound, brain MRI \\
\hline $\begin{array}{l}\text { Cardiac (for presumed coincidence with congenital } \\
\text { disorders) }\end{array}$ & Heart ultrasound \\
\hline $\begin{array}{l}\text { Classic radiological (for presumed coincidence with } \\
\text { congenital disorders) }\end{array}$ & X-ray of the chest or particular spinal sections \\
\hline $\begin{array}{l}\text { Genetical (for presumed coincidence with congenital } \\
\text { disorders) }\end{array}$ & $\begin{array}{l}\text { Dysmorphological in the direction of microdeletion } \\
\text { or microduplication (MLPA, FISH, ACGH) }\end{array}$ \\
\hline
\end{tabular}



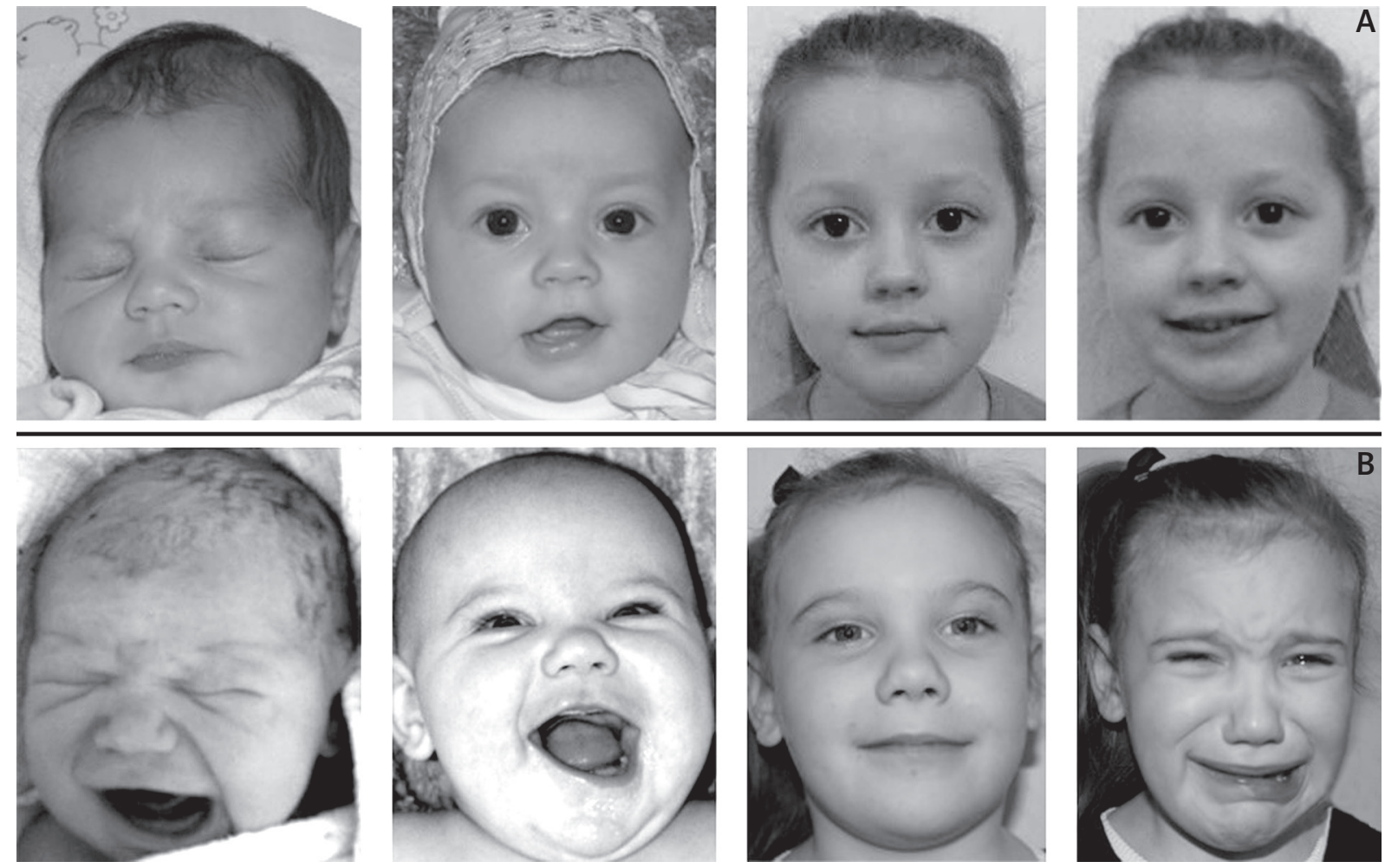

Figure 3. A clinical picture of ACF - changes with time (A - left-sided ACF, B - right-sided ACF (own material, used with the parents' permission)

muscle transposition, and hypoglossal nerve transposition [33]. The implementation of any surgical treatment is considered from the age of 2 years, namely at the age when the disappearance of the symptoms is expected, if the aetiology of ACF was connected with the compression. Attempts are now being made to use a botulinum toxin. Iskan et al. [35] are currently reporting on its efficiency in restoring facial symmetry, with its effect persisting for up to 6 months. Prognosis of ACF is highly dependent on the underlying cause, anatomical basis, and associated anomalies and complications. Successful treatment is possible at any age, as described in a case of effective chemodenervation with lidocaine in a 51-year-old woman [36].

\section{Conclusions}

A newborn baby's facial asymmetry determined at birth does not have to be a symptom of the defect of a central or peripheral facial nerve. The symmetry of the face while at rest and the lack of disorder of suction may indicate congenital hypoplasia or agenesis of the depressor anguli oris muscle, or rarely of the depressor of the edge of the mouth and depressor of labii inferioris, the condition referred to as ACF. Isolated $\mathrm{ACF}$ is treated as a cosmetic defect not requiring general implementation of either conservative or invasive treatment. However, a high percentage of occurrence of ACF and the sequence of several congenital anoma- lies should encourage doctors to extend their diagnosis, with the examination excluding a symptomatic type of the disorder. Searching for a potentially lifethreatening pathology in the central nervous system by neuroimaging is especially important in cases showing features of central facial palsy.

\section{Conflict of interest}

The authors declare no conflict of interest.

\section{References}

1. Terzis JK, Anesti K. Experience with developmental facial paralysis: Part I. Diagnosis and associated stigmata. Plast Reconstr Surg 2011; 128: 488-497.

2. Evans AK, Licameli G, Brietzke S, Whittemore K, Kenna $M$. Pediatric facial nerve paralysis: patients, management and outcomes. Int J Pediatr Otorhinolaryngol 2005; 69: 1521-1528.

3. Falco NA, Eriksson E. Facial nerve palsy in the newborn: incidence and outcome. Plast Reconstr Surg 1990; 85: 1-4.

4. Maffei G, Magaldi L, Cassano P, Cassano M, Cella A, Magaldi R. Reversible facial nerve palsy secondary to nasal continuous positive airway pressure. J Perinat Med 2008; 36: 550-551.

5. Cheong YW, Lo LJ. Facial asymmetry: etiology, evaluation, and management. Chang Gung Med J 2011; 34: 341-351.

6. Sapin SO, Miller AA, Bass HN. Neonatal asymmetric crying facies: a new look at an old problem. Clin Pediatr 2005; 44: 109-119. 
7. Renault F. Facial electromyography in newborn and young infants with congenital facial weakness. Dev Med Child Neurol 2001; 43: 421-427.

8. Pasick C, McDonald-McGinn DM, Simbolon C, Low D, Zackai E, Jackson O. Asymmetric crying facies in the 22q11.2 deletion syndrome: implications for future screening. Clin Pediatr 2013; 52: 1144-1148.

9. Lahat E, Heyman E, Barkay A, Goldberg M. Asymmetric crying facies and associated congenital anomalies: prospective study and review of the literature. J Child Neurol 2000; 15: 808-810.

10. Dubnov-Raz G, Merlob P, Geva-Dayan K, Blumenthal D, Finkelstein Y. Increased rate of major birth malformations in infants with neonatal "asymmetric crying face": a hospital-based cohort study. Am J Med Genet A 2007; 143: 305-310.

11. Ekici A, Çarman KB, Özdemir Ö, Küçükçongar A, Ekici MA. Congenital Marin-Amat syndrome and asymmetric crying face: a case report. Int J Brain Disord Treat 2016; 2: 010.

12. White FA. Physical signs in medicine and surgery. In: Physical Signs in Medicine and Surgery an Atlas of Rare, Lost and Forgotten Physical Signs. White FA (eds). Museum Press Books, Philadelphia 2009.

13. Lin DS, Huang FY, Lin SP, Chen MR, Kao HA, Hung HY, $\mathrm{Hsu} \mathrm{CH}$. Frequency of associated anomalies in congenital hypoplasia of depressor anguli oris muscle: a study of 50 patients. Am J Med Genet 1997; 7: 215-218.

14. Daly SB, Urquhart JE, Hilton E, McKenzie EA, Kammerer RA, Lewis M, Kerr B, Stuart H, Donnai D, Long DA, Burgu B, Aydogdu O, Derbent M, Garcia-Minaur S, Reardon W, Gener B, Shalev S, Smith R, Woolf AS, Black GC, Newman WG. Mutations in HPSE2 cause urofacial syndrome. Am J Hum Genet 2010; 86: 963-969.

15. Stuart HM, Roberts NA, Burgu B, Daly SB, Urquhart JE, Bhaskar S, Dickerson JE, Mermerkaya M, Silay MS, Lewis MA, Olondriz MB, Gener B, Beetz C, Varga RE, Gülpınar O, Süer E, Soygür T, Ozçakar ZB, Yalçınkaya F, Kavaz A, Bulum B, Gücük A, Yue WW, Erdogan F, Berry A, Hanley NA, McKenzie EA, Hilton EN, Woolf AS, Newman WG. LRIG2 mutations cause urofacial syndrome. Am J Hum Genet 2013; 92: 259-264.

16. Bay A, Aktekin E, Ergun S, Ozen S. Asymmetrical crying face concomitant with Glanzmann's thrombasthenia. Blood Coagul Fibrinolysis 2014; 25: 186-187.

17. Van Dijk FS, van Thuijl HF, Wermeskerken A, van Rijn RR, Cobben JM. Solitary median maxillary central incisor and congenital nasal pyriform aperture stenosis combined with asymmetric crying facies and postaxial lower limb reduction defects: a unique combination of features. Eur J Med Genet 2011; 54: 284-286.

18. Caksen H, Patiroğlu T, Ciftçi A, Cikrikçi V, Ceylaner S. Asymmetric crying facies associated with hemihypertrophy: report of one case. Acta Paediatr Taiwan 2003; 44: 98-100.

19. Rai B, Mallick D, Thapa R, Biswas B. Cayler cardiofacial syndrome with situs inversus totalis. Eur J Pediat 2014; 173: $1675-1678$.

20. Akcakus M, Koklu E, Narin N, Kose M. Clinical and microscopic hair features of griscelli syndrome associated with asymmetric crying facies in an infant. Pediatr Dev Pathol 2008; 11: 63-65.

21. Akçakuş M, Güneş T, Kurtoğlu S, Ozturk A. Collodion baby associated with asymmetric crying facies: a case report. Pediatr Dermatol 2003; 20: 134-136.
22. Voudris KA, Skardoutsou A, Vagiakou EA. Congenital asymmetric crying facies and agenesis of corpus callosum. Brain Dev 2003; 25: 133-136.

23. Caksen H, Odabaş D, Tuncer O, Kirimi E, Tombul T, Ikbal M, Ataş B, Ari Yuca S. A review of 35 cases of asymmetric crying facies. J Genet Couns 2004; 15: 159-165.

24. Cayler GG. Cardiofacial syndrome. Arch Dis Child 1969; 44: 69-75.

25. Shashi V, Berry MN, Hines MH. Vasomotor instability in neonates with chromosome 22q11 deletion syndrome. Am J Med Genet A 2003; 121A: 231-234.

26. Fu CH, Leung $\mathrm{C}$, Kao $\mathrm{CH}$, Yeh SJ. Noncardiac DiGeorge syndrome diagnosed with multiplex ligation-dependent probe amplification: a case report. J Formos Med Assoc 2015; 114: 769-773.

27. Karagol BS, Zenciroglu A. Asymmetric crying facies with a couple of primary mandibular central incisor and 22q11 deletion. J Clin Pediatr Dent 2010; 34: 343-345.

28. Akçakuş M, Güneş T, Kurtoğlu S, Cetin N, Ozkul Y, Narin N, Atabek ME, Uğraş R. Asymmetric crying facies associated with congenital hypoparathyroidism and 22q11 deletion. Turk J Pediatr 2004; 46: 191-193.

29. Shimasaki N, Watanabe K, Hara M, Kosaki K. EYA1 mutation in a newborn female presenting with cardiofacial syndrome. Pediatr Cardiol 2004; 25: 411-413.

30. Van der Aa N, Rooms L, Vandeweyer G, van den Ende J, Reyniers E, Fichera M, Romano C, Delle Chiaie B, Mortier G, Menten B, Destrée A, Maystadt I, Männik K, Kurg A, Reimand T, McMullan D, Oley C, Brueton L, Bongers EM, van Bon BW, Pfund R, Jacquemont S, Ferrarini A, Martinet D, Schrander-Stumpel C, Stegmann AP, Frints SG, de Vries BB, Ceulemans B, Kooy RF. Fourteen new cases contribute to the characterization of the 7q11.23 microduplication syndrome. Eur J Med Genet 2009; 52: 94-100.

31. Somerville MJ, Mervis CB, Young EJ, Seo EJ, del Campo M, Bamforth S, Peregrine E, Loo W, Lilley M, Pérez-Jurado LA, Morris CA, Scherer SW, Osborne LR. Severe expressive-language delay related to duplication of the WilliamsBeuren locus. N Engl J Med 2005; 353: 1694-1701.

32. Nelson KB, Eng GD. Congenital hypoplasia of the depressor anguli oris muscle: differentiation from congenital facial palsy. J Pediatr 1972; 81: 16-20.

33. Udagawa A, Arikawa K, Shimizu S, Suzuki H, Matsumoto $\mathrm{H}$, Yoshimoto S, Ichinose $\mathrm{M}$. A simple reconstruction for congenital unilateral lower lip palsy. Plast Reconstr Surg 2007; 120: 238-244.

34. Kosins AM, Keith BS, Hurvitz A. Facial paralysis for the plastic surgeon. Can J Plast Surg 2007; 15: 77-82.

35. Isken T, Gunlemez A, Kara B, Izmirli H, Gercek H. Botulinum toxin for the correction of asymmetric crying facies. Aesthet Surg J 2009; 29: 524-527.

36. Krane NA, Markey JD, Loyo M. Neuromodulator for the treatment of congenital unilateral lower lip palsy. Ann Otol Rhinol Laryngol 2019; 128: 62-65.

\section{Address for correspondence:}

\section{Agata Michalska MD}

Departament of Physiotherapy

Collegium Medicum

Jan Kochanovski University

al. IX Wieków Kielc 19a, Kielce, Poland

E-mail: michalskaagata.reh@gmail.com 